\title{
Recent patents in combinatorial chemistry
}

\begin{tabular}{|c|c|c|c|c|c|}
\hline Patent \# & Subject & Assignee & Author & Date & Status \\
\hline DE 19823747 & $\begin{array}{l}\text { New pivaloyl-oxirane or diol derivatives, used as photolabile } \\
\text { linkers for solid-phase synthesis in combinatorial chemistry. }\end{array}$ & $\begin{array}{l}\text { Novartis } \\
\text { (Basel, Switzerland) }\end{array}$ & - & 12/2/1999 & A1 \\
\hline WO 9959722 & $\begin{array}{l}\text { A three-dimensional array of solid-phase supports to provide } \\
\text { parallel synthesis of a library of molecules with three- } \\
\text { dimensional diversity. }\end{array}$ & $\begin{array}{l}\text { Selectide Corp. } \\
\text { (Tucson, AZ) }\end{array}$ & $\begin{array}{l}\text { Baum SA, } \\
\text { Stein DT }\end{array}$ & $11 / 25 / 1999$ & A1 \\
\hline WO 9958475 & $\begin{array}{l}\text { A process for effecting multistep, high-yield, automated } \\
\text { organic synthesis for application in combinatorial chemistry. }\end{array}$ & $\begin{array}{l}\text { Cambridge } \\
\text { Combinatorial Ltd. } \\
\text { (Cambridge, UK) }\end{array}$ & $\begin{array}{l}\text { Bolli M, } \\
\text { Gervois A, } \\
\text { Habermann J, } \\
\text { Hall B, Haunert F, } \\
\text { Hinzen B, Ley S, } \\
\text { Scott J }\end{array}$ & $11 / 18 / 1999$ & $\mathrm{~A} 2$ \\
\hline WO 9956866 & $\begin{array}{l}\text { An apparatus for marking beads useful in combinatorial } \\
\text { chemistry. }\end{array}$ & $\begin{array}{l}\text { Central Research } \\
\text { Laboratories Ltd. } \\
\text { (Hayes, UK) }\end{array}$ & Corless AR & $11 / 11 / 1999$ & A1 \\
\hline $\begin{array}{l}\text { JP } 11304786 \\
\text { EP } 886143\end{array}$ & $\begin{array}{l}\text { An apparatus for screening compound libraries using frontal } \\
\text { chromatography in combination with mass spectrometry; } \\
\text { allows the relative affinity of each member of the library } \\
\text { for the target receptor to be determined relative to other } \\
\text { members under ligand-receptor binding conditions, for } \\
\text { rapid ranking of the relative affinity of each member of } \\
\text { the compound library. }\end{array}$ & $\begin{array}{l}\text { Synsorb Biotech } \\
\text { (Calgary, Alberta, } \\
\text { Canada) }\end{array}$ & $\begin{array}{l}\text { Hindsgaul O, } \\
\text { Schriemer DC }\end{array}$ & $\begin{array}{l}11 / 5 / 1999 \\
12 / 23 / 1998\end{array}$ & $\begin{array}{r}\text { A } \\
\text { A1 }\end{array}$ \\
\hline US 5979251 & $\begin{array}{l}\text { A simple apparatus for the distribution of microscopic } \\
\text { substrate beads in which they are passed from a liquid } \\
\text { suspension through an aperture and into a combinatorial } \\
\text { chemistry array. }\end{array}$ & $\begin{array}{l}\text { SmithKline } \\
\text { Beecham (London) }\end{array}$ & $\begin{array}{l}\text { Hare JF, } \\
\text { James PJ, } \\
\text { Marlow J, } \\
\text { Payne RC }\end{array}$ & 11/9/1999 & A \\
\hline WO 9953319 & $\begin{array}{l}\text { High-density, miniaturized arrays of immobilized reactants } \\
\text { attached to a coating with a topographical surface area } \\
\text { larger than the projected surface area; for use in gene } \\
\text { sequencing or mapping, monitoring gene expression, } \\
\text { drug discovery, and combinatorial chemistry. }\end{array}$ & $\begin{array}{l}\text { 3M Innovative } \\
\text { Properties Co. } \\
\text { (Minneapolis, MN) }\end{array}$ & $\begin{array}{l}\text { Halverson KJ, } \\
\text { Patil SL, } \\
\text { Rasmussen JK }\end{array}$ & 10/21/1999 & A2 \\
\hline WO 9949428 & $\begin{array}{l}\text { A bead-manipulating chuck for selective pickup and discharge } \\
\text { of polymer beads for use in chemical processes, e.g., in } \\
\text { combinatorial chemistry for solid-phase synthesis, in a PCR } \\
\text { assay, or for the synthesis of pharmaceutical dosage forms. }\end{array}$ & $\begin{array}{l}\text { Sarnoff Corp. } \\
\text { (Princeton, NJ) }\end{array}$ & Sun $\mathrm{HC}$ & 9/30/1999 & A1 \\
\hline WO 9947267 & $\begin{array}{l}\text { An apparatus for integrating the processing of magnetic } \\
\text { particles; applicable in combinatorial chemistry, DNA } \\
\text { function analysis, automatic immunoassay applications. }\end{array}$ & $\begin{array}{l}\text { Precision System } \\
\text { Sci. Co. Ltd. }\end{array}$ & Tajima H & 9/23/1999 & A1 \\
\hline EP 937696 & $\begin{array}{l}\text { Safety-catch linkers useful for binding a substrate to a resin } \\
\text { or other solid support during solid-phase and combinatorial } \\
\text { solid-phase syntheses. }\end{array}$ & $\begin{array}{l}\text { IRORI } \\
\text { (San Diego, CA) }\end{array}$ & $\begin{array}{l}\text { Czarnik AW, } \\
\text { Xiao X, Xiao Y }\end{array}$ & $8 / 25 / 1999$ & $\mathrm{~A} 1$ \\
\hline WO 9941006 & $\begin{array}{l}\text { A method of fabricating coded particles, particularly } \\
\text { coded security particles and coded combinational } \\
\text { chemistry support particles. }\end{array}$ & $\begin{array}{l}\text { Univ. of } \\
\text { Hertfordshire } \\
\text { (Herts, UK) }\end{array}$ & $\begin{array}{l}\text { Greenaway RS, } \\
\text { Kaye PH, } \\
\text { Tracey MC }\end{array}$ & 8/19/1999 & $\mathrm{A} 1$ \\
\hline WO 9930817 & $\begin{array}{l}\text { A chemical synthesis apparatus with reagent inputs, a } \\
\text { solid-reaction beads input, and reaction chambers, for } \\
\text { use in combinatorial chemistry for synthesis of potential } \\
\text { drug candidate molecules. The chambers have a barrier } \\
\text { that prevents the passage of solid beads but allows } \\
\text { passage of unbound molecules. }\end{array}$ & Kalibrant Ltd. (UK) & $\begin{array}{l}\text { French MT, } \\
\text { Palmer DA }\end{array}$ & 6/24/1999 & $\mathrm{A} 1$ \\
\hline JP 11147890 & $\begin{array}{l}\text { Solid phase-supported optically active phosphine, used in } \\
\text { combinatorial chemistry or high-speed synthesis using an } \\
\text { autosynthetic apparatus. }\end{array}$ & $\begin{array}{l}\text { Nissan Chemical } \\
\text { Industries Ltd. (Tokyo) }\end{array}$ & - & 6/2/1999 & A \\
\hline
\end{tabular}

Source: Derwent Information, Alexandria, VA. ${ }^{\star}$ The patents in the table are pending. The status of each application is slightly different from country to country. For further details, contact Derwent Information, 1725 Duke St., Suite 250, Alexandria, VA 22314. Tel: 1 (800) DERWENT (info@derwent.com). 